\title{
Pregled poticaja za razvoj pedijatrijskih lijekova i broja pedijatrijskih kliničkih ispitivanja faze III u izabranim državama
}

\section{Review of incentives for pediatric drug development and of the number of phase III clinical trials in selected countries}

\author{
Erna Knežević ${ }^{1}$, Doris Rušić ${ }^{1}$, Josipa Bukić ${ }^{1}$, Joško Božić ${ }^{2}$, Ana Šešelja Perišin ${ }^{1}$, Dario Leskur ${ }^{1}$, \\ Darko Modun ${ }^{1}$, Siniša Tomić ${ }^{1,3^{*}}$
}

\begin{abstract}
Sažetak. Procjenjuje se da više od 50 \% lijekova korištenih u EU-u u pedijatrijske svrhe nikada nije bilo ispitano u toj populaciji. Cilj ovog članka bio je pregledati zakone i poticaje na klinička ispitivanja u pedijatrijskoj populaciji i usporediti ih s brojem kliničkih ispitivanja u pedijatrijskoj populaciji faze III koje financiraju industrije, kao i udjelom pedijatrijskih u ukupnom broju kliničkih ispitivanja faze III posljednjih deset godina. Napravljen je pregled poticaja za klinička ispitivanja u pedijatrijskoj populaciji i zakonskih okvira koji ih reguliraju za osamnaest država različite razvijenosti i EU. Za države uključene u istraživanje napravljen je pregledan broj pedijatrijskih kliničkih ispitivanja faze III koje je financirala industrija i njihova udjela u ukupnom broju kliničkih ispitivanja faze III koje je financirala industrija, registriranih u bazi clinicaltrials.gov u razdoblju od 2008. do 2017. godine. Najčešće usvojeni poticaji za razvoj pedijatrijskih lijekova bili su SPC ili višegodišnja patentna zaštita. Razvijeno zakonodavstvo sa sustavom obveza za njihovo provođenje imaju EU, SAD i Švicarska. Razvijene države imaju strogo regulirano zakonodavstvo i formirane poticaje za pedijatrijska klinička ispitivanja, ali se ispitivanja često provode u nerazvijenim državama zbog jednostavnosti i cijene. U EU-u, Japanu i Švicarskoj uočeni su trendovi porasta broja pedijatrijskih kliničkih ispitivanja nakon uvođenja inicijativa i poticaja za njihovo provođenje. Utvrđene su nejednakosti u stupnju reguliranosti obveze provođenja kliničkih ispitivanja u pedijatrijskoj populaciji među državama. Nije utvrđena povezanost broja ili udjela pedijatrijskih u ukupnom broju kliničkih ispitivanja faze III i stupnja regulacije obveza i poticaja za provođenje pedijatrijskih kliničkih ispitivanja u pojedinoj državi.
\end{abstract}

Ključne riječi: farmaceutsko zakonodavstvo; klinička ispitivanja faze III; pedijatrijski lijekovi
${ }^{1}$ Katedra za farmaciju, Sveučilište u Splitu, Medicinski fakultet, Split

${ }^{2}$ Katedra za patofiziologiju, Sveučilište u Splitu, Medicinski fakultet, Split

${ }^{3}$ Agencija za lijekove i medicinske proizvode, Zagreb
*Dopisni autor:

Izv. prof. dr. sc. Siniša Tomić Agencija za lijekove i medicinske proizvode Ksaverska cesta 4, 10000 Zagreb e-mail:sinisa.tomic@halmed.hr legislation and formed incentives for pediatric clinical trials, but research is often conducted in underdeveloped states for simplicity and price. In the EU, Japan and Switzerland, an increasing trend in the number of pediatric clinical trials have been observed after

http://hrcak.srce.hr/medicina 
introducing initiatives and incentives to encourage them. Inequalities in the degree of regulation of the obligation to carry out clinical trials in pediatric population among states have been established. There was no link between the number or the proportion of pediatric patients in the total number of phase III clinical trials and the degree of regulation of the obligations and incentives for pediatric clinical trials in a particular country.

Key words: clinical trial, phase III; Legislation, pharmacy; pediatric drugs

Prema podacima baze clinicaltrials.gov u EU-u broj kliničkih ispitivanja u pedijatrijskoj populaciji raste od 2008. do 2017. godine nakon uvedene Pedijatrijske uredbe.

\section{UVOD}

Procjenjuje se da više od 50 \% lijekova, korištenih u Europskoj uniji (EU) u pedijatrijske svrhe nikada nije bilo ispitano u toj populaciji. Ovi lijekovi najčešće su ispitani u odrasloj populaciji i ne nužno u istoj indikaciji u kojoj se primjenjuju u pedijatrijskoj populaciji ${ }^{1}$. Zbog toga se često pribjegava offlabel načinu primjene lijekova u pedijatrijskoj populaciji, odnosno primjeni izvan uvjeta za koje je lijek dobio odobrenje za stavljanje u promet ${ }^{2}$. Podaci o primjeni lijekova ekstrapoliraju se iz podataka za odraslu populaciju, zbog čega doziranje predstavlja glavni izazov u terapijama pedijatrijske populacije ${ }^{3-4}$. No, svaki lijek korišten u praksi, koji nije ispitan u kliničkim ispitivanjima, može se smatrati eksperimentom ${ }^{5}$. Zakonodavni čimbenici, manjak gospodarskog interesa farmaceutske industrije, odraz negativnih rezultata na upotrebu lijeka u odrasloj populaciji te odgođene neželjene reakcije na lijekove uzrok su nedostataka podataka o primjeni lijekova u pedijatrijskoj populaciji, što tu populaciju dovodi do statusa 'terapijske siroča$\mathrm{di}^{\prime 6-8}$. Američka pedijatrijska akademija nalaže kako tretiranje pedijatrijske populacije neispitanim lijekovima predstavlja veći rizik od njena uključivanja u klinička ispitivanja ${ }^{9}$. Postoje, međutim, posebne odredbe za klinička ispitivanja u pedijatrijskoj populaciji, vezane uz proces informiranog pristanka i prihvatljivosti rizika, koje predstavljaju posebne izazove za klinička ispitivanja na toj populaciji ${ }^{5}$, stoga je zbog ograničenog broja kontroliranih randomiziranih ispitivanja vrlo teško ili gotovo nemoguće znati sve potencijalne koristi ili rizike određenog kliničkog ispitivanja u pedijatrijskoj populaciji ${ }^{10}$.

Potreba za regulacijom i poticanjem kliničkih ispitivanja u pedijatrijskoj populaciji javila se tijekom godina nakon rješavanja raznih etičkih pitanja $\mathrm{i}$ posljedica koje su se dogodile zbog nedostatka podataka o primjeni lijekova u tom području. U pregled je uključeno 18 država različitog stupnja razvijenosti i EU (slika 1). Za uključene države napravljen je pregled zakonskih okvira koji reguliraju klinička ispitivanja u pedijatrijskoj populaciji, odnosno registraciju lijekova za pedijatrijsku populaciju. Nadalje, pregledane su publikacije i smjernice agencija za lijekove pojedine države. Izvršen je pregled i znanstvenih publikacija i publikacija stručnih organizacija koje se bave problematikom ispitivanja sigurnosti primjene lijekova u pedijatrijskoj populaciji i dostupnosti lijekova za pedijatrijsku populaciju. Za države uključene $u$ istraživanje prikazan je broj pedijatrijskih kliničkih ispitivanja faze III i njihov udio u ukupnom broju kliničkih ispitivanja faze III registriranih u bazi clinicaltrials.gov. Spomenuta baza izabrana je jer sadržava podatke 304418 kliničkih ispitivanja iz 209 država svijeta, a sučelje za pretraživanje dozvoljava pretragu samo istraživanja koja je financirala industrija. Baza je pretražena za svaku od promatranih država posebno i za svaku promatranu godinu zasebno u razdoblju od 2008. do 2017. godine. Za EU je pregled broja kliničkih ispitivanja izvršen za sve države članice na datum 25. rujna 2018. godine (28 država članica). Ovako prikupljeni podaci grupirani su i prikazani kao jedinstveni rezultat broja kliničkih ispitivanja u EU-u. Ograničenja korištena prilikom pretraživanja baze clinicaltrials.gov bila su sljedeća: ispitivanja 1. 1. - 31. 12. (posebno godine od 2008. do 2017.), intervencijska ispitivanja (kliničke studije) faze III koje je financirala industrija te dobne granice za djecu $(0-17)$ i sveukupnu populaciju koja uključuje djecu $(0-17)$, odrasle $(18-64)$ i starije odrasle (65+) (slika 1). Nakon ekstrakcije broja kliničkih ispitivanja u pedijatrijskoj populaciji i u svim dobnim skupinama prema zadanim ograničenjima napravljen je izračun udjela pedijatrijskih u ukupnom broju ispitivanja. Rezultati su prikazani kao pregled dostupnih zakona prema državama odnosno EU-u i kao cijeli brojevi za broj 
ispitivanja i postotci za udio pedijatrijskih u ukupnom broju ispitivanja.

\section{MEDUNARODNA REGULATIVA}

Kako bi se riješio nedostatak odgovarajućih pedijatrijskih lijekova na svjetskom tržištu, 2000. god. Međunarodna konferencija za usklađivanje (engl. the International Conference on Harmonisation; ICH) formirala je smjernicu ICH E11 koja prikazuje ključna pitanja u razvoju pedijatrijskih lijekova te osnovne pristupe kako bi se odobrila njihova primjena temeljena na etički opravdanim, sigurnim i djelotvornim kliničkim ispitivanjima provedenim u pedijatrijskoj populaciji ${ }^{2,11,12}$.

\section{SJEDINJENE AMERIČKE DRŽAVE}

U Sjedinjenim Američkim Državama (SAD) pokrenuto je više inicijativa za poticanje kliničkih ispitivanja u pedijatrijskoj populaciji. Podnositelji zahtjeva za registraciju lijeka (i biološkog lijeka, s izuzećem lijekova za rijetke bolesti) koji sadrži novu djelatnu tvar, novu indikaciju, novu formulaciju ili novi režim doziranja su obvezni zahtjevu za dobivanje odobrenja za stavljanje takvog lijeka u promet priložiti i plan ispitivanja u pedijatrijskoj populaciji (engl. Pediatric Study Plan) ${ }^{13}$. Od nosi- telja odobrenja za stavljanje lijeka u promet se može i zatražiti provođenje kliničkih ispitivanja u pedijatrijskoj populaciji u određenim uvjetima ${ }^{14}$. Nadalje, Nacionalni institut za zdravlje (engl. National Institutes of Health; NIH) sastavlja listu lijekova i terapijskih područja od posebnog interesa za ispitivanje u pedijatrijskoj populaciji, kao i prijedlog kliničkih ispitivanja u pedijatrijskoj populaciji (engl. Proposed Pediatric Study Request; PPSR). Temeljem PPSR-a Američka agencija za hranu i lijekove (engl. Food and Drug Administration; FDA) nositeljima odobrenja upućuje zahtjev za provođenje kliničkih ispitivanja ili, alternativno, nositelji odobrenja sami upute zahtjev za njihovo provođenje, pri čemu im se patentna zaštita produljuje na šest mjeseci ako ispitivanja provedu do devet mjeseci prije isteka patentne zaštite lijeka ${ }^{15-17}$. Nositelj odobrenja za lijek koji ima odobrenje za stavljanje u promet za indikaciju koja se smatra rijetkom pedijatrijskom bolesti prilikom dobivanja odobrenja dobiva i vaučer FDA-a za prioritetni pregled zahtjeva (engl. Priority review voucher). Prioritetni pregled obvezuje FDA na postupanje unutar 6 mjeseci od zaprimanja zahtjeva. Vaučer se može prenositi uz financijsku naknadu, a broj prijenosa nije ograničen ${ }^{18}$.

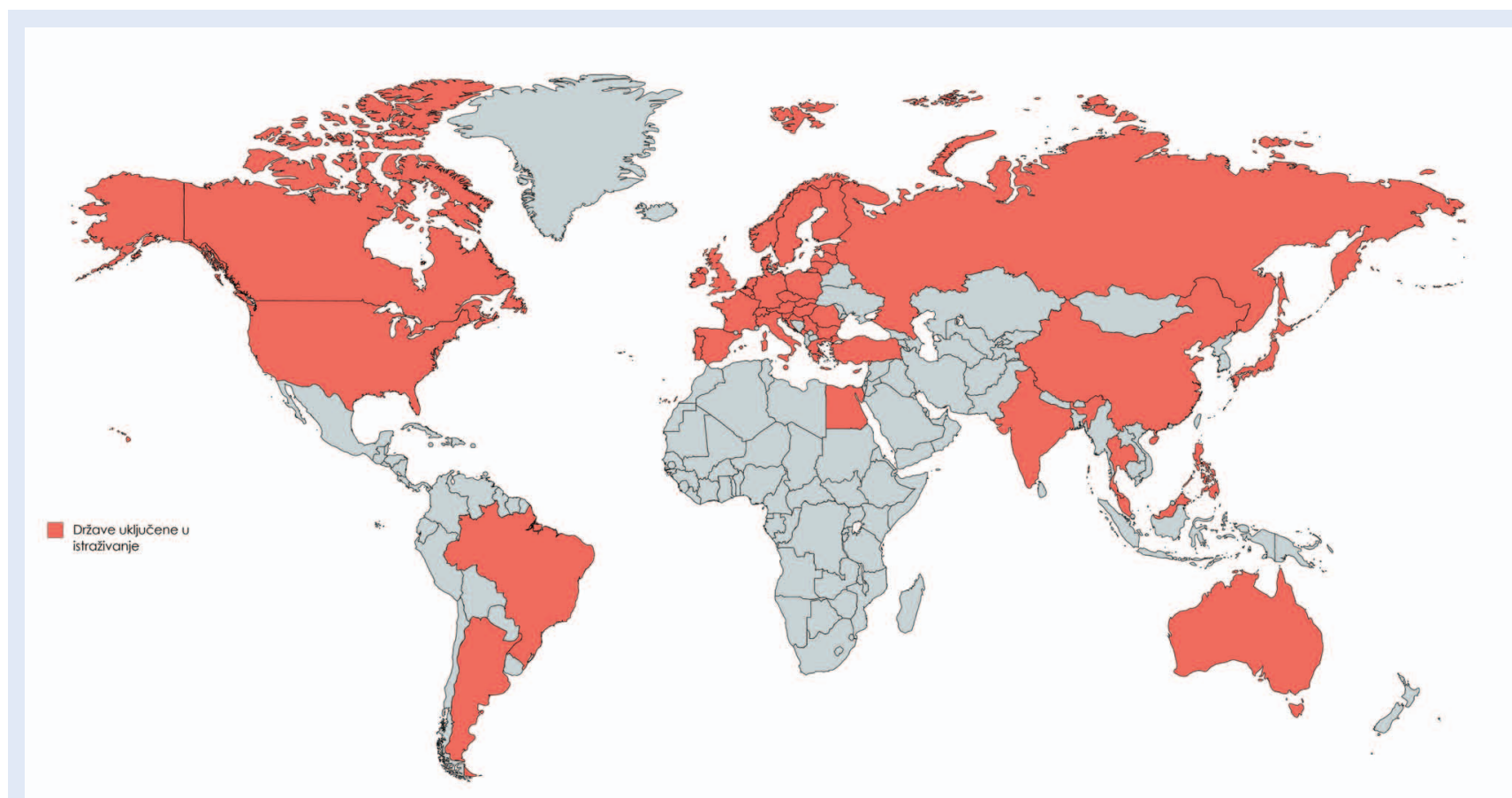

Slika 1. Države uključene u istraživanje 


\section{EUROPSKA UNIJA}

Za reguliranje lijekova u EU-u nadležna je Europska agencija za lijekove (engl. European Medicines agency; EMA $)^{19}$. Europski parlament i Vijeće EU-a 2006. god. formirali su Uredbu 1901/2006 ili tzv. Pedijatrijsku uredbu, koja je na snazi od 2007. god. ${ }^{20} \mathrm{U}$ okviru EMA-e formiran je Odbor za pedijatrijske lijekove (engl. Pediatric Committee; PDCO) čija je uloga donositi odluke i mišljenja vezane uz plan pedijatrijskog ispitivanja (engl. Pediatric Investigation Plan; PIP) koje su voditelji kliničkih ispitivanja u pedijatrijskoj populaciji obvezni dostaviti EMA-i prilikom podnošenja zahtjeva za dobivanje odobrenja za stavljanje lijeka u promet $u$ ispitivanoj dobnoj skupini ${ }^{21}$. PIP je detaljni plan razvoja pedijatrijskih lijekova koji sadrži sve podatke prikupljene prilikom kliničkih ispitivanja u pedijatrijskoj populaciji. Prijava za PIP primjenjuje se i kada nositelj odobrenja za stavljanje lijeka u promet želi proširiti indikaciju, razviti novi farmaceutski oblik ili put primjene za lijek koji već ima važeće odobrenje za stavljanje u promet i zaštićen je pravima intelektualnog vlasništva22. U EU je uspostavljen sustav nagrađivanja i poticaja za razvoj pedijatrijskih lijekova. Naime, lijekovima koji su odobreni u EU, a sadrže rezultate ispitivanja uključenih u PIP koje se nalaze u uputi o lijeku, produljuje se rok trajanja svjedodžbe o dodatnoj zaštiti (engl. supplementary protection certificate; SPC) na šest mjeseci, čak i ako su rezultati provedenih studija bili negativni. Nadalje, lijekovi razvijeni za djecu koji već imaju odobrenje za stavljanje u promet, a nemaju patentnu zaštitu ili SPC, imaju pravo na odobrenje za stavljanje lijeka u promet za pedijatrijsku upotrebu (engl. paediatric-use marketing authorisation; PUMA), što podrazumijeva da će proizvod imati desetogodišnju patentnu zaštitu ${ }^{23}$. PUMA je uvedena Pedijatrijskom uredbom za lijekove koji su odobreni, a nisu više pokriveni SPC-om ili patentom koji se kvalificira kao SPC te ako će se razviti specifično za upotrebu u pedijatrijskoj populaciji. Razvoj PUMA-e mora pratiti PIP koji će odobriti PDCO, a predviđeni poticaji su: automatski pristup centraliziranom postupku odobravanja, deset godina patentne zaštite, stavljanje lijeka u promet pod istim nazivom i brendom kao već odobreni lijek (ako sadrži istu djelatnu tvar) te godinu dana oslobođenja od financijskog sudjelovanja za centralizirani postupak za marketinško i postmarketinško odobrenje ${ }^{24}$.

\section{OSTALE DRŽAVE}

Australija je usvojila EMA-ine međunarodno priznate smjernice vezane za provedbu kliničkih ispitivanja i terapije u pedijatrijskoj populaciji, a samu Pedijatrijsku uredbu je 2007. godine usvojila i Norveška ${ }^{25,26}$. Nadalje, politika poticaja na klinička ispitivanja u pedijatrijskoj populaciji $u$ Kanadi uključuje šestomjesečno produljenje patentne zaštite ako se $u$ ispitivanje uključi barem jedan od definiranih uzrasta pedijatrijske popula$\mathrm{cije}^{27}$. Japan dodjeljuje različite duljine patente zaštite za različite vrste razvijenih lijekova, a može se produljiti i do deset godina ako se u klinička ispitivanja uključi pedijatrijska populacija ${ }^{28}$. Jedinstvenost politike poticanja na klinička ispitivanja u pedijatrijskoj populaciji u Japanu čini sustav u kojem cijene lijekova koji dolaze na tržište opadaju svake dvije godine, međutim, ako se lijek razvije u pedijatrijskoj populaciji, kao nagrada, one se neće smanjivati u dogovorenom razdoblju². Švicarska dodjeljuje produljene patentne zaštite lijeka ako se razvije za upotrebu u pedijatrijskoj populaciji, a od 2013. predviđeno je smanjenje naknade za pedijatrijska klinička ispitivanja za $90 \%$ ako se odobri novi lijek ili se točno definira njegova primjena u pedijatrijskoj populaciji. Također je u razdoblju od 2013. do 2016. godine revidiran Zakon o lijekovima i medicinskim proizvodima koji uključuje obvezu izrade pedijatrijskog plana ispitivanja za podnositelje zahtjeva za odobravanje lijekova ${ }^{29}$.

Među države koje nemaju razvijenu politiku poticanja na pedijatrijska klinička ispitivanja, kao ni razvijen sustav obveza i nagrada, spadaju Rusija, Malezija, Tajland, Filipini te Egipat ${ }^{30}$. U toj je skupini i Kina, čija je dodatna poteškoća najdulje vrijeme potrebno za dobivanje zakonodavnog i etičkog odobrenja za klinička ispitivanja na cijelom azijskom području ${ }^{31,32}$. U Indiji se pedijatrijski lijekovi razvijaju na temelju kliničkih ispitivanja na odrasloj populaciji te ne postoje posebni propisi o razvoju lijekova za pedijatrijsku populaciju ${ }^{33}$. No, ako kliničko ispitivanje zahtijeva izričito pedijatrijsku populaciju, preporuka je da se počne sa 
što starijom skupinom pedijatrijskih pacijenata prije no što se ono produlji na mlađe skupine, sve do novorođenčadi ${ }^{34}$. Brazil također nema politiku poticaja na pedijatrijska klinička ispitivanja, unatoč najpoželjnijim etničkim karakteristikama ${ }^{35,36}$. Nadalje, Argentina je vodeća država Latinske Amerike po broju pedijatrijskih kliničkih ispitivanja zbog najkraćeg vremena potrebnog za njihovo odobravanje, no ne postoji politika poticaja na njihovo provođenje ${ }^{37,30 .}$ Turska je, kao država kandidat za ulazak u EU, poduzela važne korake ka usklađivanju zakonodavstva s EU-om na području kliničkih ispitivanja, te su propisi u potpunosti u skladu s europskim direktivama 2001/20/EC i 2005/28/EC ${ }^{38,39}$. Ipak, još uvijek ne postoji politika poticaja na klinička ispitivanja u pedijatrijskoj populaciji $^{30}$. Crna Gora je usvojila smjernice Dobre kliničke prakse koje su usklađene sa smjernicama ICH E6 za dobru kliničku praksu i ICH E11 za klinička ispitivanja u pedijatrijskoj populaciji, a Srbija Direktivu 2001/20/EC, kao i smjernice Dobre kliničke prakse usklađene sa smjernicama $\mathrm{ICH}^{40,41}$.

\section{BROJ PEDIJATRIJSKIH KLINIČKIH ISPITIVANJA FAZE III}

Kretanje broja pedijatrijskih kliničkih ispitivanja faze III koje financira industrija u promatranim državama prikazano je u tablici 1 . Prema podacima baze clinicaltrials.gov u EU-u broj kliničkih ispitivanja u pedijatrijskoj populaciji raste od 2008. do 2017. godine nakon uvedene Pedijatrijske uredbe. Hrvatska je prema udjelu pedijatrijskih kliničkih ispitivanja u ukupnom broju kliničkih ispitivanja ispod prosjeka EU-a i SAD-a. U Japanu je vidljiv je trend porasta broja pedijatrijskih kliničkih ispitivanja od 2009. god., kada je udio pedijatrijskih u ukupnom broju kliničkih ispitivanja bio $14,73 \%$ te se održao u rasponu $14,73 \%$ 23,33\% do 2017. godine. U razdoblju od 2013. do 2017. godine u Švicarskoj je vidljiv porast broja kliničkih pedijatrijskih ispitivanja nakon što je provedena revizija zakona za klinička ispitivanja u pedijatrijskoj populaciji kada su uvedeni smanjenje naknade i sustav obveza za njihovo provođenje. Za Kinu je vidljiv trend pada broja pedijatrijskih kliničkih ispitivanja od 2014. - 2017. sukladno poteškoćama pri dobivanju odobrenja za njihovo provođenje (tablica 1).

https://clinicaltrials.gov/

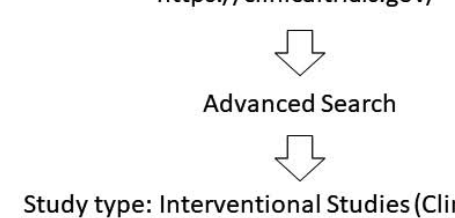

Study type: Interventional Studies (Clinical Trials) Phase: Phase III

Funder Type: Industry

Study Start: From 01/01/20XY To 31/12/20XY Locations: Country:

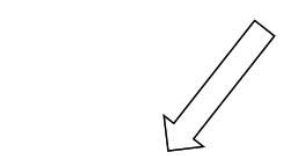

Eligibility Criteria:

Age Group:

$\checkmark$ Child (0-17)

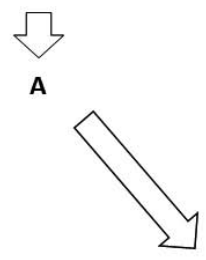

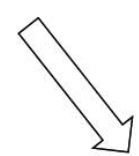

Eligibility Criteria: Age Group:

$\checkmark$ Child (0-17)

$\checkmark$ Adult (18-64)

$\checkmark$ Older Adult (65+)

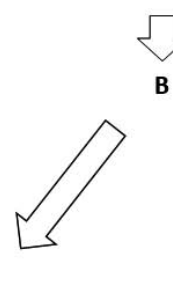

A/B

$X-0-1$

$\mathrm{Y}-1-8$

A - ukupni broj pedijatrijskih kliničkih ispitivanja faze III

A/B - udio pedijatrijskih u ukupnom broju kliničkih ispitivanja faze III

Slika 2. Algoritam pretraživanja i izračuna broja kliničkih ispitivanja

Po pitanju broja kliničkih ispitivanja akademske zajednice zajedno s farmaceutskim tvrtkama prate proces globalizacije. Štoviše, praksa razvijenih država postala je da svoja ispitivanja provode u nerazvijenim državama. Ovakvom praksom olakšava se regrutiranje pacijenata jer im je u nerazvijenim državama nerijetko to jedini način da dođu do potrebnog lijeka. Stoga, s obzirom na financijska i zakonodavna pitanja, vođenje kliničkih ispitivanja u nerazvijenim krajevima olakšano je farmaceutskim tvrtkama, iako, paradoksalno, razvijene države nude poticaje za njih ${ }^{47}$. Roditelji i kliničari se, opet, često odlučuju na standardnu zdravstvenu skrb, a ne na sudjelovanje u ispitivanju, zbog nesigurnosti prilikom odabira najbolje opcije za pedijatrijskog pacijenta ${ }^{48}$.

Promatrajući broj kliničkih ispitivanja faze III, valja istaknuti kako stranica clinicaltrials.gov nije obvezujuća stranica za prijavu kliničkih ispitiva- 
Tablica 1. Broj pedijatrijskih kliničkih ispitivanja i njihov udio u ukupnom broju kliničkih ispitivanja faze III koje financira industrija

\begin{tabular}{|c|c|c|c|c|c|c|c|c|c|c|c|}
\hline \multicolumn{2}{|l|}{ Država } & 2008. & 2009. & 2010. & 2011. & 2012. & 2013. & 2014. & 2015. & 2016. & 2017. \\
\hline \multirow{2}{*}{ EU* } & $\mathrm{N}$ & 364 & 335 & 332 & 522 & 487 & 494 & 535 & 483 & 495 & 549 \\
\hline & $\%$ & 12,85 & 13,45 & 12,52 & 18,54 & 17,72 & 17,46 & 18,84 & 16,15 & 18,81 & 20,69 \\
\hline \multirow{2}{*}{ Hrvatska } & $\mathrm{N}$ & 5 & 6 & 2 & 3 & 6 & 11 & 3 & 5 & 7 & 6 \\
\hline & $\%$ & 7,4 & 4,5 & 16,0 & 15,0 & 6,2 & 3,1 & 10,0 & 7,4 & 5,3 & 4,2 \\
\hline \multirow{2}{*}{ SAD } & $\mathrm{N}$ & 122 & 113 & 113 & 128 & 107 & 103 & 123 & 128 & 131 & 123 \\
\hline & $\%$ & 19,77 & 21,04 & 21,28 & 23,97 & 21,06 & 19,07 & 22,74 & 21,44 & 23,86 & 22,53 \\
\hline \multirow{2}{*}{ Japan } & $\mathrm{N}$ & 7 & 19 & 31 & 32 & 35 & 24 & 35 & 23 & 30 & 31 \\
\hline & $\%$ & 6,93 & 14,73 & 23,31 & 18,82 & 21,08 & 16,9 & 23,33 & 15,86 & 18,29 & 17,92 \\
\hline \multirow{2}{*}{ Australija } & $\mathrm{N}$ & 20 & 16 & 13 & 24 & 24 & 25 & 30 & 31 & 28 & 36 \\
\hline & $\%$ & 13,33 & 11,94 & 9,03 & 16,9 & 16,78 & 14,2 & 17,96 & 17,92 & 10,14 & 21,69 \\
\hline \multirow{2}{*}{ Kanada } & $\mathrm{N}$ & 36 & 42 & 30 & 38 & 37 & 46 & 44 & 41 & 55 & 58 \\
\hline & $\%$ & 14,12 & 18,58 & 12,82 & 17,51 & 15,35 & 18,18 & 17,39 & 16,27 & 23,01 & 24,17 \\
\hline \multirow{2}{*}{ Švicarska } & $\mathrm{N}$ & 7 & 9 & 5 & 6 & 5 & 9 & 10 & 11 & 14 & 10 \\
\hline & $\%$ & 10,94 & 16,07 & 8,06 & 10,91 & 8,62 & 15,79 & 16,39 & 14,67 & 21,54 & 19,23 \\
\hline \multirow{2}{*}{ Norveška } & $\mathrm{N}$ & 4 & 5 & 3 & 7 & 9 & 4 & 3 & 3 & 5 & 5 \\
\hline & $\%$ & 8,33 & 13,51 & 9,68 & 21,21 & 26,47 & 8,16 & 7,69 & 11,54 & 14,71 & 14,29 \\
\hline \multirow{2}{*}{ Rusija } & $\mathrm{N}$ & 25 & 27 & 25 & 37 & 31 & 36 & 32 & 21 & 28 & 32 \\
\hline & $\%$ & 14,88 & 17,09 & 16,89 & 18,59 & 17,22 & 19,25 & 19,51 & 13,73 & 16 & 19,88 \\
\hline \multirow{2}{*}{ Turska } & $\mathrm{N}$ & 7 & 10 & 10 & 16 & 20 & 22 & 24 & 10 & 21 & 16 \\
\hline & $\%$ & 10,45 & 17,54 & 17,86 & 28,57 & 29,41 & 24,44 & 26,97 & 12,99 & 24,42 & 21,05 \\
\hline \multirow{2}{*}{ Crna Gora } & $\mathrm{N}$ & 0 & 0 & 0 & 0 & 1 & 2 & 1 & 0 & 0 & 0 \\
\hline & $\%$ & 0 & 0 & 0 & 0 & 50 & 66,67 & 50 & 0 & 0 & 0 \\
\hline \multirow{2}{*}{ Srbija } & $\mathrm{N}$ & 9 & 10 & 3 & 12 & 7 & 9 & 6 & 5 & 12 & 10 \\
\hline & $\%$ & 19,15 & 34,48 & 10,34 & 20 & 17,95 & 23,68 & 15,38 & 9,62 & 20 & 24,39 \\
\hline \multirow{2}{*}{ Brazil } & $\mathrm{N}$ & 17 & 22 & 19 & 30 & 23 & 16 & 20 & 16 & 13 & 17 \\
\hline & $\%$ & 12,88 & 16,67 & 15,57 & 23,44 & 22,12 & 15,38 & 20,41 & 16,67 & 15,29 & 16,5 \\
\hline \multirow{2}{*}{ Argentina } & $\mathrm{N}$ & 17 & 13 & 13 & 22 & 10 & 13 & 20 & 11 & 9 & 15 \\
\hline & $\%$ & 15,89 & 13,83 & 13,68 & 22,92 & 10,75 & 12,75 & 21,74 & 12,64 & 10,84 & 19,23 \\
\hline \multirow{2}{*}{ Kina } & $\mathrm{N}$ & 12 & 15 & 10 & 14 & 18 & 13 & 11 & 7 & 11 & 8 \\
\hline & $\%$ & 14,12 & 18,29 & 11,49 & 15,05 & 19,15 & 12,04 & 11,96 & 7 & 13,58 & 7,21 \\
\hline \multirow{2}{*}{ Indija } & $\mathrm{N}$ & 23 & 20 & 12 & 19 & 10 & 8 & 8 & 6 & 6 & 11 \\
\hline & $\%$ & 18,25 & 20,83 & 10,43 & 22,89 & 22,22 & 19,05 & 21,05 & 24 & 17,65 & 22,45 \\
\hline \multirow{2}{*}{ Malezija } & $\mathrm{N}$ & 7 & 6 & 4 & 9 & 12 & 9 & 12 & 6 & 5 & 8 \\
\hline & $\%$ & 19,44 & 19,35 & 8,89 & 29,03 & 27,27 & 21,95 & 33,33 & 23,08 & 16,13 & 23,53 \\
\hline \multirow{2}{*}{ Tajland } & $\mathrm{N}$ & 9 & 7 & 5 & 13 & 14 & 8 & 14 & 6 & 6 & 9 \\
\hline & $\%$ & 15,52 & 12,28 & 10 & 28,26 & 29,79 & 17,78 & 25,93 & 14,29 & 18,18 & 27,27 \\
\hline \multirow{2}{*}{ Filipini } & $\mathrm{N}$ & 9 & 5 & 11 & 16 & 16 & 11 & 14 & 1 & 8 & 9 \\
\hline & $\%$ & 17,65 & 12,5 & 20,37 & 40 & 41,03 & 29,73 & 32,56 & 5 & 38,1 & 33,33 \\
\hline \multirow{2}{*}{ Egipat } & $\mathrm{N}$ & 0 & 3 & 1 & 3 & 2 & 2 & 2 & 3 & 3 & 0 \\
\hline & $\%$ & 0 & 15 & 5,88 & 37,5 & 18,18 & 20 & 25 & 42,86 & 75 & 0 \\
\hline
\end{tabular}

*Računato kao suma kliničkih ispitivanja u državama članicama EU-a 1. rujna 2018. godine

Izvor: clinicaltrials.gov 
nja, pa neke države možda imaju mali broj registriranih kliničkih ispitivanja u ovoj bazi jer postoji mogućnost da je dio kliničkih ispitivanja registriran u drugim bazama. Nadalje, uzimajući u obzir limitacije sučelja za pretraživanje clinicaltrials.gov, broj kliničkih ispitivanja koji je izračunat u EU-u je preuveličan jer je računat kao suma kliničkih ispitivanja za sve države članice EU-a u 2018. godini. Istom metodom je izračunat i broj ukupnih kliničkih ispitivanja faze III, pa možemo pretpostaviti da izračunati udio kliničkih ispitivanja u pedijatrijskoj populaciji u ukupnom broju kliničkih ispitivanja odgovara stvarnom udjelu. U određenim državama se ne provodi velik broj kliničkih ispitivanja faze III koje financira industrije, pa udio pedijatrijskih u ukupnom broju kliničkih ispitivanja ispada značajno velik, a primjeri takvih država su Crna Gora i Egipat. Konačno, pregled zakonodavstva za pedijatrijske lijekove različitih država bio je ograničen na javno dostupne informacije.

\section{ZAKLJUČAK}

Poticaji na klinička ispitivanja u pedijatrijskoj populaciji dio troškova povećavaju, dok dio smanjuju. Povećavaju se troškovi agencija koje dodjeljuju poticaje za razvoj lijekova u pedijatriji, međutim povećanjem znanja o terapiji u pedijatrijskoj skupini dugoročno se smanjuju cjelokupni troškovi liječenja ${ }^{42}$. Najčešće usvojeni poticaji za razvoj lijekova u spomenutoj populaciji su SPC te višegodišnja patentna zaštita, predloženi Pedijatrijskom uredbom. Ovi poticaji povećavaju troškove zdravstvene zaštite jer odgađaju uvođenje generičkih lijekova. To u konačnici znači prihod nositelju odobrenja za stavljanje u promet lijeka, ali trošak zdravstvenom sustavu države koja je ovakvu politiku usvojila ${ }^{42}$. Usvojeni programi i zakoni doveli su do povećanja broja kliničkih ispitivanja u pedijatrijskoj populaciji istovremeno smanjujući troškove njihova pokretanja kroz poticaje i nagrade ${ }^{43}$. Klinička ispitivanja u pedijatrijskoj populaciji doživjela su polagan ali velik napredak po pitanju međunarodnog priznavanja njihove važnosti. Ključ ovog uspjeha je suradnja na nacionalnoj i međunarodnoj razini među glavnim zakonodavnim tijelima, farmaceutskim i znanstvenim zajednicama, kliničarima i društvu u cjelini ${ }^{44}$. Rezultat je kolaboracija najutjecajnijih svjetskih organizacija $u$ području lijekova: EMA, FDA i ICH, a sve kako bi se optimizirala primjena lijekova u pedijatrijskoj populaciji ${ }^{45}$. FDA centri održavaju mjesečne konferencijske pozive „Pedijatrijske skupine” s kolegama specijaliziranim za pedijatrijska klinička ispitivanja iz EU-a, Australije, Kanade i Japana. FDA i EMA su formirale jednostrani dokument nazvan 'Zajedničko tumačenje' (engl. Common Commentary) kojim obavještavaju sponzore o raspravama i važnim zaključcima od strane regulatornih tijela ${ }^{46}$. Ovaj pregled pokazuje da postoje

Nije utvrđena povezanost udjela pedijatrijskih u ukupnom broju kliničkih ispitivanja faze III sa stupnjem regulacije obveza i poticaja za provođenje pedijatrijskih kliničkih ispitivanja u pojedinoj državi.

nejednakosti u stupnju reguliranosti obveze provođenja kliničkih ispitivanja novih lijekova u pedijatrijskoj populaciji među državama. U najvećem broju država uključenih u istraživanje su usvojene $\mathrm{ICH}$ smjernice, smjernice Dobre proizvođačke prakse i smjernice EU-a.

Izjava o sukobu interesa: Autori izjavljuju da ne postoji sukob interesa.

\section{LITERATURA}

1. The European pediatric initiative: History of the Pediatric Regulation. [Internet]. EMEA17967/04. 2007 [cited 2018 Sep 28]. Available Available from: https://www. ema.europa.eu/en/documents/other/european-paediatric-initiative-history-paediatric-regulation_en.pdf.

2. Tsukamoto K, Carroll KA, Onishi T, Matsumaru N, Brasseur D, Nakamura H. Improvement of pediatric drug development: regulatory and practical frameworks. Clin Ther 2016;38:574-81.

3. Hill P. Off licence and off label prescribing in children: litigation fears for physicians. Arch Dis Child 2005;90 Suppl 1:17-8.

4. Zisowsky J, Krause A, Dingemanse J. Drug Development for Pediatric Populations: Regulatory Aspects. Pharmaceutics 2010;2:364-88.

5. Kleiber N, Tromp K, Mooij MG, Vathorst S, Tibboel D, Wildt S. Ethics of drug research in the pediatric intensive care unit. Pediatr Drugs 2014;17:43-53.

6. Baroukh MA. Therapeutic Orphans: European Perspective. Pediatrics 1999;104:591-2.

7. Shirkey HC. Therapeutic Orphans - Everybody's business. Ann Pharmacother 2006;40;1174.

8. Ross LF. 50 Years Ago in The Journal of Pediatrics: Editorial Comment: Therapeutic Orphans. J Pediatr 2018;192: 59. 
9. Naspitz CK, Warner JO. Children are pharmaco-therapeutic orphans. Pediatr Allergy Immunol 2010;21:249-50.

10. Ward RM, Sherwin CMT. Ethics of Drug Studies in the Newborn. Pediatr Drugs 2014;17:37-42.

11. Uredbe, direktive i ostali pravni akti - Europska unija European Commission [Internet]. Europska unija. 2018 [cited 2018 Sep 20]. Available from: https://europa.eu/ european-union/eu-law/legal-acts_hr.

12. Clinical Investigation of Medicinal Products in the Pediatric Population E11. [Internet] ICH. 2011. [cited $2018 \mathrm{Sep}$ 28]. Available from: https://www.ema.europa.eu/en/ documents/scientific-guideline/international-conference-harmonisation-technical-requirements-registrationpharmaceuticals-human-use_en-30.pdf.

13. Pediatric Research Equity Act of 2003. Public Law 108155, 2003. [cited 2018 Sep 20]. Available from: https:// www.gpo.gov/fdsys/pkg/PLAW-108publ155/pdf/PLAW108publ155.pdf.

14. Guidance for Industry: How to Comply with the Pediatric Research Equity Act (Draft Guidance). Food and Drug Administration. 2005. [cited 2018 Sep 28]. Available from: https://www.fda.gov/downloads/drugs/guidancecomplianceregulatoryinformation/guidances/ ucm079756.pdf.

15. Written Requests Issued [Internet]. Fda.gov. 2018 [cited 2018 Sep 28]. Available from: https://www.fda.gov/dru$\mathrm{gs/developmentapprovalprocess/developmentresour-}$ ces/ucm050002.htm.

16. Qualifying for Pediatric Exclusivity Under Section 505A of the Federal Food, Drug, and Cosmetic Act: Frequently Asked Questions on Pediatric Exclusivity (505A) [Internet]. Fda. gov. 2018 [cited 2018 Sep 28]. Available from: https://www.fda.gov/drugs/developmentapprovalprocess/developmentresources/ucm077915.htm.

17. Pediatric studies of drugs. 21 U.S.C. $\$ 355$ a [cited 2018 Sep 28]. Available from: http://uscode.house.gov/view. xhtml ? req $=($ title: $21 \% 20$ section: 355 a \% 20 edition:prelim)\%200R\%20(granuleid:USC-prelim-title21-section355a)\& $f=$ treesort\&edition=prelim\&num $=0$ \&jumpTo=true.

18. Priority review to encourage treatments for rare pediatric diseases. 21 U.S.C. §360 ff [cited 2018 Sep 28]. Available from: http://uscode.house.gov/view. xhtml ? req = (title: $21 \% 20$ section: $360 f$ f $\% 20$ edition:prelim)\%200R\%20(granuleid:USC-prelim-title21-section360ff)\&f=treesort\&edition=prelim\&num=0 \&jumpTo=true.

19. What we do | European Medicines Agency [Internet]. Ema.europa.eu. 2018 [cited 2018 Sep 23]. Available from: https://www.ema.europa.eu/en/about-us/whatwe-do.

20. Uredba (EZ) br. 1901/2006 Europskog parlamenta i Vijeća od 12. prosinca 2006. o lijekovima za pedijatrijsku upotrebu i izmjeni Uredbe (EEZ) br. 1768/92, Direktive 2001/20/EZ, Direktive 2001/83/EZ i Uredbe (EZ) br. 726/2004. Publications.europa.eu. 2007 [cited 2018 Sep 24]. Available from: https://publications.europa.eu/en/ publication-detail/-/publication/f02fd0de-82a9-42d89cd1-723176bb5ce0/language-hr.

21. Paediatric medicines: Overview | European Medicines Agency [Internet]. Ema.europa.eu. 2018 [cited 2018 Sep 24]. Available from: https://www.ema.europa.eu/en/ human-regulatory/overview/paediatric-medicines-overview.
22. Paediatric investigation plans | European Medicines Agency [Internet]. Ema.europa.eu. 2018 [cited 2018 Sep 24]. Available from: https://www.ema.europa.eu/en/ human-regulatory/research-development/paediatricmedicines/paediatric-investigation-plans.

23. Rewards and incentives for paediatric medicines | European Medicines Agency [Internet]. Ema.europa.eu. 2018 [cited 2018 Sep 24]. Available from: https://www.ema. europa.eu/en/human-regulatory/research-development/paediatric-medicines/rewards-incentives-paediatric-medicines.

24. Paediatric-use marketing authorisations | European Medicines Agency [Internet]. Ema.europa.eu. 2018 [cited 2018 Sep 24]. Available from: https://www.ema.europa. eu/en/human-regulatory/marketing-authorisation/paediatric-medicines/paediatric-use-marketing-authorisations.

25. Information relating to paediatrics [Internet]. Therapeutic Goods Administration (TGA). 2018 [cited 2018 Oct 3]. Available from: https://www.tga.gov.au/book-page/110information-relating-paediatrics.

26. The Pediatric Regulation implemented in Norway - Advokatfirmaet Haavind [Internet]. Haavind EN. 2018 [cited 2018 Oct 8]. Available from: https://haavind.no/en/ news/the-pediatric-regulation-will-finally-be-implemented-in-norway/.

27. Canada H. Guidance Document: Data Protection under C.08.004.1 of the Food and Drug Regulations - Canada. ca [Internet]. Canada.ca. 2018 [cited 2018 Oct 5]. Available from: https://www.canada.ca/en/health-canada/ services/drugs-health-products/drug-products/applications-submissions/guidance-documents/guidance-document-data-protection-under-08-004-1-food-drug-regulations.html\#a4.

28. Hirata M. Pediatric drug development in Japan and International Regulatory Collaboration [Internet]. Tokyo; 2017 [cited 2018 Oct 2]. Available from: http://www. pmda.go.jp/files/000224497.pdf.

29. Medicines for children [Internet]. Swissmedic.ch. 2017 [cited 2018 Oct 7]. Available from: https://www.swissmedic.ch/swissmedic/en/home/humanarzneimittel/ besondere-arzneimittelgruppen--ham-/paediatrie. html.

30. The Role of Regulatory Policy on the Pediatric Therapies of Tomorrow [Internet]. San Francisco: University of California, Schools of Pharmacy and Medicine, Department od Bioengineering and Therapeutic Sciences; 2017 [cited 2018 Oct 10]. Available from: http://file:///C:/Users/ Korisnik/Downloads/ACDRS2017-pedsworkshop_BucciiRechtweg_1.pdf.

31. Li Z, Wang Y, Wu D, Gao X, Wang Z. Current Status of Pediatric Labeling in China and the near Future Efforts Needed for the Country. Front Pediatr 2014;2:17.

32. Sheraz A, Oluwaseun E, Zaheer Ud DB, Syed Shahzad H. Challenges of conducting clinical trials in Asia. Ali S et al. Int J Clin Trials 2018;5:194-9.

33. Venkatensh MP. Regulation for Peadiatric Drug Development in India: Need of the Hour. Journal for Clinical Studies 2014;6:14-7.

34. The Drugs and Cosmetics Act and Rules [Internet]. Government of India, Ministry of Health and Family Welfare (Department of Health); 2005 [cited 2018 Oct 21]. Available from: http://dfda.goa.gov.in/images/PDF-DOCUMENTS/Drugs--Cosmetics-Act.pdf. 
35. Da Costa PQ, Rey LC, Coelho HL. Lack of drug preparations for use in children in Brazil. J Pediatr (Rio J) 2009; 85:229-35.

36. Fagundes $P$, Dresel P, Miller A. Brazil's Regulatory Environment Offers Positive Changes for Clinical Trials [Internet]. 2018 [cited 2018 Oct 19]. Available from: http:// file:///C:/Users/Korisnik/Downloads/2018\%20June\%20 Regulatory\%20Focus\%20Brazil\%20Fagundes\%20Dresel\%20Miller.pdf.

37. Mulberg A, Murphy D, Dunne J, Mathis L. Pediatric drug development CONCEPTS AND APPLICATIONS [Internet]. 2nd ed. 2018 [cited 2018 Oct 19]. Available from: https:// books.google.hr/books?id=BGINKD7k2ccC\&pg=PT644\&lp $\mathrm{g}=$ =PT644\&dq=russia+pediatric+drug+development\&sourc e=bl\&ots=mL5PCYfR8f\&sig=eMPa49p77rgN4SCyOVbqjZp r5Rw\&hl=hr\&sa=X\&ved=2ahUKEwibopjyypLeAhUPOxoKH WlaAACQ6AEwA3oECAYQAQ\#v=onepage $\& q=$ russia $\% 20$ pediatric\%20drug\%20development\&f=false.

38. Zemlje - Europska unija - European Commission [Internet]. Europska unija. 2018 [cited 2018 Oct 17]. Available from: https://europa.eu/european-union/about-eu/countries hr\#28-dr\%C5\%BEava-\%C4\%8Dlanica-europskeunije.

39. Ilbars H. Clinical Trials in Turkey. Turk J Haematol 2013; 30:111-4.

40. Klinička ispitivanja - Regulativa [Internet]. Agencija za ljekove i medicinska sredstva Crne Gore. 2018 [cited 2018 Oct 18]. Available from: https://www.calims.me/ Portal/faces/dinamickeStrane?_afrLoop $=227241138896$ 2286\& paramPut $=+\% 3 \mathrm{E}+\mathrm{Klini} \% \mathrm{C} 4 \% 8 \mathrm{Dka}$ +ispitivanja $+\% 3$ $\mathrm{E}+$ Regulativa\&paramRender $=1 \&$ paramS $=86 \&$ _adf.ctrlstate=b1yhektpx_68.
41. Klinička ispitivanja [Internet]. Alims.gov.rs. 2018 [cited 2018 Oct 18]. Available from: https://www.alims.gov.rs/ latin?s=klini\%C4\%8Dka+ispitivanja.

42. Weigmann K. The ethics of global clinical trials. 2015;16: 566-70.

43. Caldwell PHY, Murphy SB, Butow PN, Craig JC. Clinical trials in children. Lancet 2004;364:803-11.

44. The Pediatric Exclusivity Provision [Internet]. Department of Health and Human Services, U.S. Food and Drug Administration; 2001 [cited 2018 Oct 25]. Available from: https://www.fda.gov/downloads/Drugs/DevelopmentApprovalProcess/DevelopmentResources/ UCM049915.pdf.

45. Do the Rewards of Pediatric Exclusivity Outweigh the Benefits? Researchers Discuss [Internet]. Raps.org. 2018 [cited 2018 Oct 27]. Available from: https://www.raps. org/news-and-articles/news-articles/2018/9/do-therewards-of-pediatric-exclusivity-outweight?feed=Regulatory-Focus.

46. Joseph PD, Craig JC, Caldwell PHY. Clinical trials in children. Br J Clin Pharmacol 2015;79:357-69.

47. Stanulović M, Stanulović V. Nove međunarodne smjernice i upute za ispitivanja na djeci. Paediatr Croat 2010; 54:1-6.

48. Califf R. Best Pharmaceuticals for Children Act and Pediatric Research Equity Act [Internet]. Department of Health and Human Services, Food and Drug Administration; 2016 [cited 2018 Oct 27]. Available from: http:// file://C:/Users/Korisnik/Downloads/FINAL\%20 2016\%20BPCA\%20and\%20PREA\%20Report\%20to\%20 Congress.pdf. 